\title{
The Expression Levels of Klotho, Endothelial Nitrite Oxide Synthetase and Catalase Genes of the Heart Tissues of Young and Old Rats
}

\author{
Genç ve Yaşlı Ratların Kalp Dokularında Klotho, Endotelial Nitrit Oksit Sentetaz ve Katalaz \\ Genlerinin Ifade Düzeyleri
}

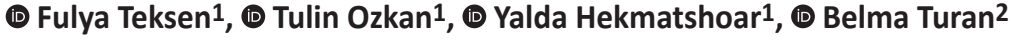 \\ ${ }^{1}$ Ankara University Faculty of Medicine, Department of Medical Biology, Ankara, Turkey \\ ${ }^{2}$ Ankara University Faculty of Medicine, Department of Biophysics, Ankara, Turkey
}

\section{Abstract}

Objectives: In order to evaluate the role of genes in aging process in the heart of rats, the expression levels of Klotho (KL), Endothelial nitrite oxide synthase (e-NOS) and Catalase (CAT) genes, which are thought to be important in the metabolism, were investigated in the present study.

Materials and Methods: The expression levels of these genes were compared in heart tissues of 24-month-old and 6-month-old male Wistar rats using real time polymerase chain reaction method.

Results: The mRNA level of e-NOS gene was increased significantly in the left side of the hearts of old rats, it was also increased in the right side of the heart, but it was not statistically significant. The mRNA level of CAT gene was decreased significantly in only the left side of the old rat heart compared to that of the young rat. Furthermore, our data on mRNA level of CAT gene determined in the right part of the heart were increased in that of old rats compared to those of the young rats. However, the expression level of $K L$ gene was not significantly different in the left part of the hearts in either old rats or young rats, whereas the expression level of this gene was increased significantly in the right side of the old rat heart compared to that of young rat heart.

Conclusion: $K L$, e-NOS and CAT expressions were thought to be effective in the heart tissue of rats in aging process. Further detailed studies that should be designed on this subject could play important role in the diagnosis and treatment of cardiovascular diseases in which the occurrence risk is increased by the aging process.

Key Words: Klotho (KL), Endothelial Nitrite Oxide Synthase (e-NOS), Catalase (CAT), Aging, Heart Tissue

\section{Özet}

Amaç: Bu çalışmada rat kalp dokularında yaşlanma metabolizmasında önemli olduğu düşünülen Klotho (KL), Endotelial nitrik oksit sentaz (e-NOS), Katalaz (CAT) genlerinin, yaşlanma ile ortaya çıkabilecek gen ifade düzeyleri ve meydana gelen değişiklikler incelenmiştir.

Gereç ve Yöntem: Bu genlerin ifade düzeyleri 24 aylık ve 6 aylık erkek Wistar ratların kalp dokularında eş zamanlı polimeraz zincir reaksiyonu yöntemi kullanılarak karşılaştırılmıştır.

Bulgular: Elde edilen sonuçlar değerlendirildiğinde, e-NOS mRNA düzeyi yaşlı ratların sol kalp bölgesinde belirgin olarak yüksek bulunmuş, aynı grubun kalplerinin sağ kısmında da yüksek olmasına rağmen istatistiksel olarak anlamlı olmadığı görülmüştür. CAT geni, mRNA düzeyi yaşlı rat kalp dokularının sadece sol kısmında genç ratlara göre anlamlı olarak düşük bulunmuştur. Diğer taraftan, yaşlı ratların sağ kalp kısmındaki dokuda ölçülen katalaz mRNA düzeyi, genç ratların aynı bölgesinden elde edilen dokudaki katalaz mRNA düzeyi ile karşılaştıııldığında daha yüksek bulunmuştur. Ancak, $K L$ geninin ifadesi gerek genç ve gerekse yaşlı ratların kalp dokularının sol kısmında anlamlı olarak farklılık göstermemiş olup, aynı grubun sağ bölgesinde ise yaşlı ratlarda genç ratlara göre, gen ifade düzeyinin anlamlı olarak arttığı saptanmıştır.

Sonuç: Yaşlanma olgusunda, KL, e-NOS ve CAT genlerinin rat kalp dokusunda etkin olabileceği düşünülmektedir. Bu alanda yapılacak daha detaylı çalışmaların, yaşlanma ile görünme riski artan kardiyovasküler hastalıkların tanı ve tedavisinde önemli rol oynayabileceği düşünülmektedir. Anahtar Kelimeler: Klotho (KL), Endotelial Nitrik Oksit Sentaz (e-NOS), Katalaz (CAT), Yaşlanma, Kalp Dokusu

Address for Correspondence/Yazışma Adresi: Prof. Dr. Fulya Teksen, MD,

Ankara University Faculty of Medicine, Department of Medical Biology, Ankara, Turkey

Phone: +90 3125958074 E-mail: fteksen58@windowslive.com ORCID: orcid.org/0000-0001-8762-1579

Received/Geliş: 18.10.2019 Accepted/Kabul: 31.05.2020

๑Copyright 2020 Ankara University Faculty of Medicine

Journal of Ankara University Faculty of Medicine is published by Galenos Publishing House.

All content are under CC BY-NC-ND license. 


\section{Introduction}

Senescence is known as an inevitable biologic end-stage of the life, however, the exact mechanism of genetic pathways regulating this aging process is not clearly understood yet. Some of the well-known hallmarks of aging include the genomic instability, increased amount of mutations, altered metabolism, decreased mitochondrial function, increased amount of free oxygen radicals, altered intercellular communication, shortening of telomeres, loss of proteostasis, stem cell exhaustion, epigenetic alterations, and deregulated nutrient sensing (1). On the other hand, one of the high-risk diseases observed in the old individuals is cardiovascular diseases. In this regard, the observations obtained from some model organism such as $C$. elegans, mice, rats, give us a lot of knowledge about the molecular mechanisms of aging and the diseases related with aging, such as cardiovascular diseases.

Early studies showed that Klotho (KL) gene was first identified by Kuro-o et al. (2), and this gene basically expressed in kidneys and as a trans-membrane protein. It acts as an essential coreceptor of fibroblast growth factor 23 (FGF23) and in the heart, the other form of the protein, soluble Klotho (s-Klotho) is the circulating form and takes role in the protection of systolic dysfunction (3). In rats, the membrane-bound form $\mathrm{KL}$ is more prevalent, whereas the secreted form is faintly expressed (4). It has been also shown that KL protein has numerous functions, involving, besides others, regulation of Insulin Like Growth Factor 1 (IGF1)/insulin signaling pathway and suppresses oxidative stress $(5,6)$. KL protein also inhibits the phosphorylation of transcription factors forkhead box 0 (FOXO), which then increase the expression of antioxidant enzymes, one of them being Catalase (CAT), thereby protecting against oxidative stress (7).

CAT is one of the important ubiquitous enzymes of the antioxidant system which reduces Reactive oxygen species (ROS) amount by degradation of $\mathrm{H}_{2} \mathrm{O}_{2}$ (peroxide) produced during cellular metabolism. It is also recently shown that, the aerobic exercise significantly improved rat survival by increasing $\mathrm{KL}$ mRNA and protein expressions and decreasing ROS levels in the brain and kidney tissues of rats (4). In addition, in some studies, it is reported that secreted KL protects the cardiovascular system through the endothelial nitric oxide synthase (e-NOS) production, most probably, through increases in Nitric oxide (NO) production with KL (8).

It is well-accepted that NO is produced within cells by the actions of a group of enzymes called nitric oxide synthases, and, endothelial nitric oxide synthase (e-NOS or NOS3) is responsible for the regulation of blood pressure and located in endothelial tissue, cardiac myocytes and hippocampal pyramidal cells. In vivo studies in the heart, using e-NOS knockout mice or NO donor have shown that NO inhibits neutrophil-mediated damage to the endothelial cells by preventing neutrophil adhesion and results in myocardial protection by preserving endothelial function. Therefore, it is clearly understood that the e-NOS synthesis regulates arterial pressure and is malformed in human hypertension. In that regard, a deficiency in NO production may maintain a reasonable mechanism for linking cardiovascular diseases in all organisms including human beings. From that point, one can emphasize that klotho protein can play an important role in this stage by regulating the production of NO (7).

Taken into consideration the known and suggestions, we in the present study, we aimed to investigate the expression levels of $K L$, e-NOS and CAT genes in the heart of old rats compared to those of young rats as well as considering their left and right parts. Indeed, literature data already mentioned the critical roles of these genes in the protection of heart tissue, maintenance of vascularization and removal of free oxygen radicals from the cells while these pathways are also intersecting closely with each other.

\section{Materials and Methods}

\section{Animals and Experimental Design}

All experimental procedures were performed in accordance with the standards of the European Community guidelines on the care and use of laboratory animals and approved by the Ankara University with a reference number of 2016-18-165 in accordance with the guide for the care and use of laboratory animals. We used 6-month-old (young group: body weights ranging between $319 \mathrm{~g}$ to $343 \mathrm{~g})(\mathrm{n}=7)$ and 24-month-old (old group: body weights ranging between $375 \mathrm{~g}$ to $388 \mathrm{~g}$ ) $(n=7)$ Wistar Male rats. All animals were exposed to a 12hour light-dark cycle in standard animal housing rooms and were fed standard food with free access to tap water. The rats were anesthetized with pentobarbital sodium $(30 \mathrm{mg} / \mathrm{kg}$ by intraperitoneal injection), then hearts and kidney were quickly removed and frozen for later RNA extraction. Kidney tissue was used as a positive control for KL primer optimization.

Cardiac dysfunction of age animals was validated in a previous study by monitoring their systemic oxidative stress and antioxidant capacity status, insulin resistance, fasting blood glucose level and the ratio of heart weight to body weight compared to those of adult rats (9).

\section{Real-time RT-PCR}

In order to detect the mRNA expression levels of e-NOS, $C A T$ and $K L$ genes, we used quantitative real-time (reverse transcription polymerase chain reaction) RT-PCR. Briefly, 
ventricular tissue was homogenized and total RNA was isolated using Trizol reagent. Subsequently, chloroform extraction and isopropanol precipitation of RNA were performed according to the manufacturer's protocol. RNA quantity and purity were determined by measuring the absorbance of RNA at $260 \mathrm{~nm}$ and the absorbance ratio was calculated at $260 / 280 \mathrm{~nm}$, respectively, using a NanoDrop spectrophotometer (Bio-Tek Instrument Model: Box998, USA).

cDNA was generated from RNA by reverse transcriptase (Transcriptor High Fidelity cDNA Synthesis Kit; Roche). Quantitative real-time RT-PCR was performed using SYBR Green PCR Master Mix (Roche) on the LC480 instrument. mRNA was measured relative to hypoxanthine phosphoribosyltransferase (HPRT) as an endogenous control. The primer sequences are

\begin{tabular}{|c|c|c|}
\hline Genes & Forward & Reverse \\
\hline e-NOS & CGAGTAAAGAATTGGGAAGTG & CAGCGTCTTGAGGTACAG \\
\hline CAT & GAAACCCACAGACTCACC & GTCACTGAACAAGAAAGAAAC \\
\hline$K L$ & TGGCПтतСТCCПTACCTG & ATCCCACAGATAGACATTCGG \\
\hline$H P R T$ & TGACACTGGTAAAACAATGCA & GGTCCIITCACCAGCAAGCT \\
\hline
\end{tabular}

given in Table 1.

\section{Statistical Analysis}

Comparisons between young and old groups were made by t-tests analysis where applicable.

$\mathrm{P}<0.05$ and $\mathrm{p}<0.001$ values was used as the cut-off for defining statistically significant differences.

\section{Results}

Expression Levels of e-NOS, CAT and $K L$ Genes in Left Ventricular Heart Tissue from Old Rats Compared to Young Rats

We evaluated the expression levels of e-NOS, CAT and $K L$ which play important roles in the aging process. The e-NOS gene expression level was increased significantly $(287.6 \pm 177.5 \%$; $\mathrm{p} \leq 0.05)$ in old rats compared to those of young rats, whereas CAT expression level was decreased significantly $(28.9 \pm 17.32 \%$; $\mathrm{p} \leq 0.001$ ) in old rats compared to young rats. The $K L$ gene expression was also slightly decreased $(89.8 \pm 494.04 \%, p>0.05)$ in old rats, but it was not statistically significant as shown in Figure 1.

Expression Levels of e-NOS, CAT and $K L$ Genes in Right Heart Tissue from Old Rats Compared to Young Rats

Both e-NOS (127.64 \pm 63.86\%, $p>0.05)$ and CAT

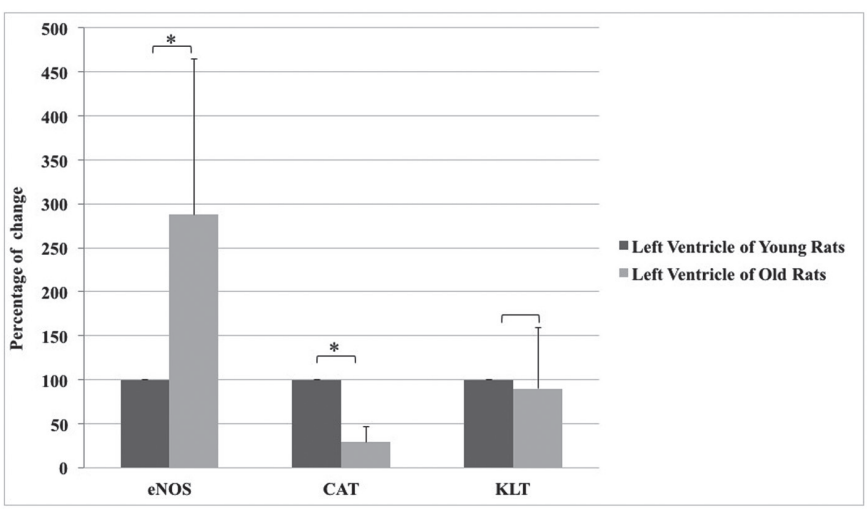

Figure 1: The mRNA expression levels of genes e-NOS, CAT and $K L$ in the left ventricle of rat tissues $\left(\mathrm{p} \leq 0.05^{*}\right)$

mRNA: Messenger RNA, e-NOS: Endothelial nitric oxide synthase, CAT: Catalase, KL: Klotho, HPRT: Hypoxanthine phosphoribosyltransferase

(248.41 $\pm 241.46 \% ; p>0.05)$ gene expression levels were detected higher in old rats compared to young rats, however these changes were not found statistically significant. Moreover, statistically significant $(494.04 \pm 70.06 \%, p \leq 0.001)$ up-regulation of $K L$ gene was observed in the right ventricle tissue of old rats compared

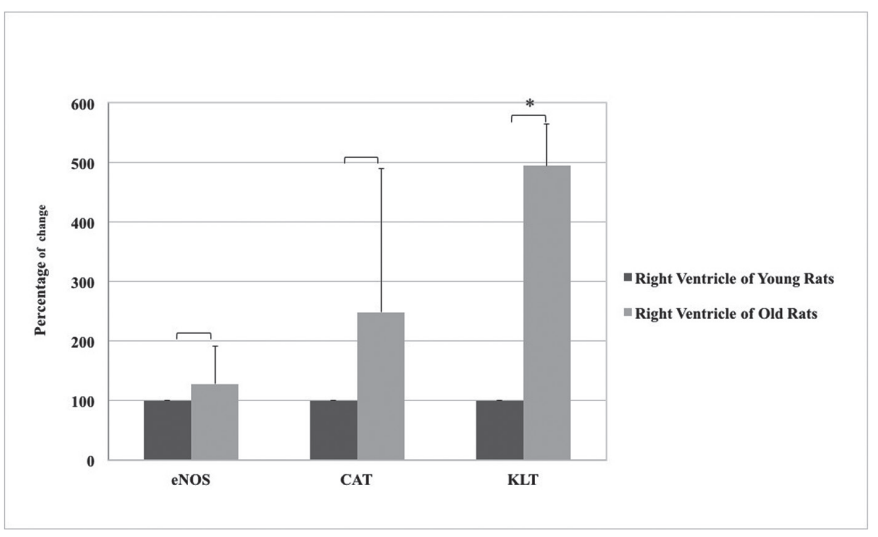

Figure 2: The mRNA expression levels of genes e-NOS, CAT and $K L$ in the right ventricle of rat tissues $\left(p \leq 0.05^{*}\right)$

mRNA: Messenger RNA, e-NOS: Endothelial nitric oxide synthase, CAT: Catalase, $\mathrm{KL}$ : Klotho, HPRT: Hypoxanthine phosphoribosyltransferase

to young rats (Figure 2).

Expression Levels of e-NOS, CAT and KL Genes in Right and Left Ventricular Heart Tissue from Old Rats

e-NOS gene expression level was increased significantly $(313.93 \pm 193.51 \% ; p \leq 0.05)$ in left ventricular tissue of old rats in comparison to right ventricular tissue of old rats, whereas CAT and $K L$ gene expression levels were significantly decreased $(17.72 \pm 10.63 \% ; p \leq 0.05$ and $12.80 \pm 9.9 \% ; p \leq 0.05$ respectively) in left ventricular tissue of old rats compared to the right ventricular tissue of old rats (Figure 3).

Expression Levels of e-NOS, CAT and KL Genes in Right 


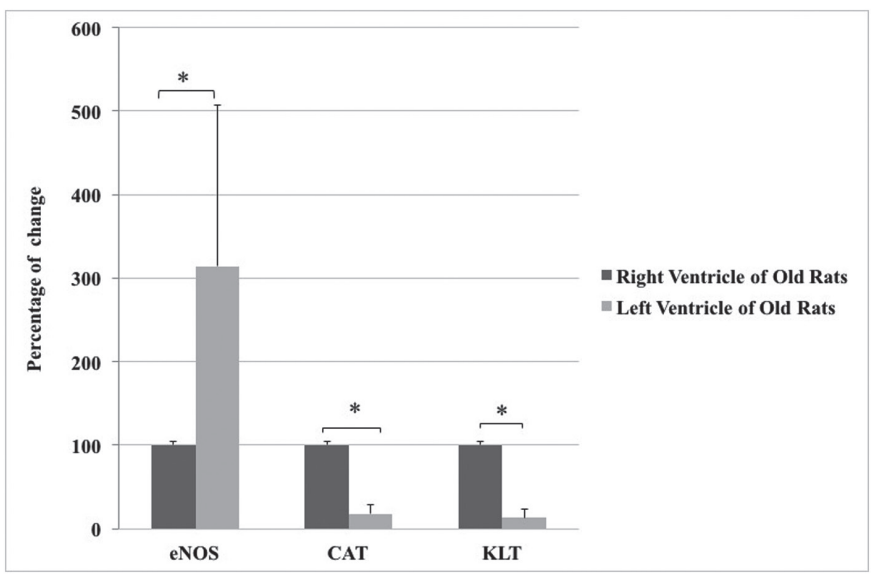

Figure 3: The mRNA expression levels of genes e-NOS, CAT and $K L$ in right and left ventricle of old rat tissues ( $\left.\mathrm{p} \leq 0.05^{*}\right)$

mRNA: Messenger RNA, e-NOS: Endothelial nitric oxide synthase, CAT: Catalase, KL: Klotho, HPRT: Hypoxanthine phosphoribosyltransferase

\section{and Left Ventricular Heart Tissue from Young Rats}

e-NOS and CAT gene expression levels were increased $(160.10 \pm 145.46 \% ; p>0.05$ and $165.65 \pm 206.17 \% ; p>0.05)$ in left ventricular tissue in comparison to the right ventricular tissue of young rats, respectively. On the other hand, $K L$ gene expression level was decreased $(97.44 \pm 70.55 \% ; p>0.05)$ in left ventricular tissue compared to the right ventricular tissue of

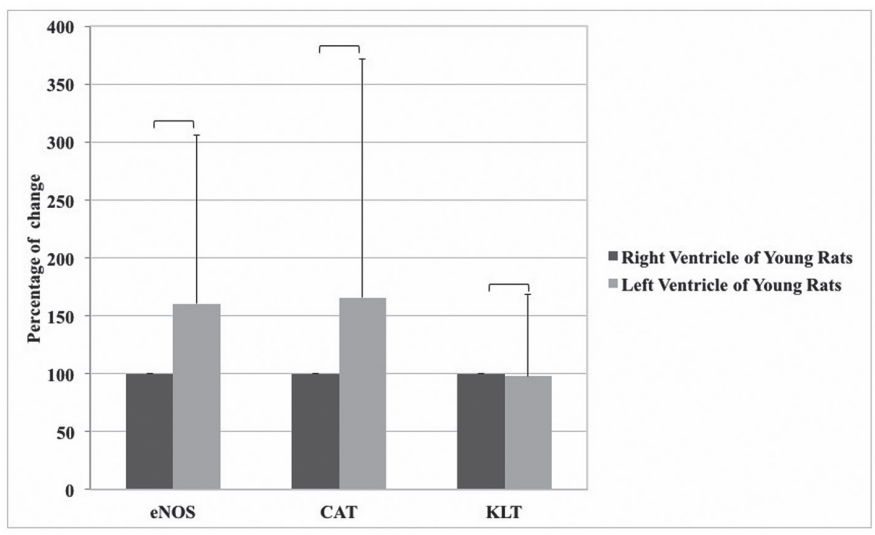

Figure 4: The mRNA expression levels of genes e-NOS, CAT and $K L$ in right and left ventricle of young rat tissues

mRNA: Messenger RNA, e-NOS: Endothelial nitric oxide synthase, CAT: Catalase, KL: Klotho, HPRT: Hypoxanthine phosphoribosyltransferase

young rats. All these gene expression levels were not statistically significant (Figure 4).

\section{Discussion}

The exact mechanism of aging is not understood yet, but some of the genes were shown to be effective in this process. Among these genes $K L, C A T$ and e-NOS genes were reported to be playing an important role in both aging and the development of aging-associated diseases like cardiovascular disorders. In addition, the low plasma KL level and other genetic variants have been reported to be associated with atherosclerosis, oxidative stress, endothelial dysfunction, which are closely related to increased risk of cardiovascular diseases and stroke in mammals, including rats and humans (10).

As reported by many investigators, the mutation in $K L$ gene results in multiple aging-like phenotypes and on the other hand, overexpression of the same gene was shown to extending lifespan by $20-30 \%$ (5). Expression levels of $K L$ gene differ significantly according to varying species of organisms and to the different tissues of these organisms. For instance, in rats, Mitani et al. (11) reported negative gene expression in aorta and heart, whereas Jimbo et al. (12) detected KL expression in aorta of normal rats. Similarly, we could measure expression level of $K L$ gene in heart tissue of some rats, but we did not detect mRNA expression level of KL in the other group of rats. On the other hand, we could measure the expression level of the same gene in the kidney of rats and it was quite high compared to the heart tissue. We also detected different expression level of $K L$ gene in the right and the left side of the heart tissue. Since our study is the first investigation in which expression levels of these genes were evaluated in the right and left parts of the heart of rats, it was not possible to compare these results with any other study. It was concluded that, the relates subjects needs more observation and discussion, that will be obtained by the future studies.

Aizawa et al. (13) reported the downregulation of kidney $\mathrm{KL}$ protein in rats under stress conditions. Similarly, in rodents, $\mathrm{s}-\mathrm{KL}$ was shown to be exerting cardioprotection through downregulation of TRPC6 calcium channels (14). Activation of $\mathrm{PI} 3 \mathrm{~K}$ and downstream Akt signaling cascade in heart was shown to be important for physiological cardiac growth, but it can also lead to pathological cardiac hypertrophy (14).

In addition, in the present study, the expression levels of $K L$ gene in the heart tissues of some rats could not be detected but in some of the heart tissues of other rats in study group low expression levels of $\mathrm{KL}$ were observed and because of this fact, the number of the rats were too small to be evaluated precisely. On the other side, the high expression level observed in the kidney tissue of rats in our experiments, performed just to compare the results and to test the method in which, the results were in concordance with other studies (15).

In 2016, Alhusseini et al. (16), again using real time PCR method, demonstrated that combined exercise training with vitamin E treatment for 8 weeks, on rats, resulted with a significant improvement in oxidative stress effect on cardiac tissue by the decrease in tumor necrosis factor alfa expression in heart and increase in $K L$ gene expression in kidney $(17,18)$. 
In the study of Dehghani et al. (19) cardiac expression levels of CAT and sulfur dioxygenase (SDO) genes decreased in the aginginduced male Wistar rats. In our study, CAT gene expression level was also decreased in the left ventricular heart tissue of old rats in comparison with the young rats so our results are correlated with these studies. Torella et al. (20) observed a decrease in vascular expression of basal e-NOS in elderly animals. Their data also indicate that aging virtually eliminates e-NOS vascular expression and its phosphorylation after balloon injury (20). Moreover, Griecsova et al. (21) observed the effect of age and preconditioning on the levels of e-NOS proteins in 1.5-3-6 months male Wistar rats. The effect of age was indicated by significantly lower levels of e-NOS proteins in 6 months and 3 months compared with control groups (1.5 months) (21).

Those results mentioned in the above paragraphs are in contrast with our findings: in here, we observed a significant increase of e-NOS in the left ventricle of the heart tissue of old rats. We evaluated this result as a protective mechanism for the vascularization system of the heart. In fact, in the pathophysiology hypertension, it is known that by the increase in age, the systolic blood pressure increases, and the cascade of activation of RAS, Angiotensin activation II, increase in NADPH/ NADH oxidase production in vascular smooth muscle and release of reactive oxygen species resulting in NO production occurs (7). Similar to our results, Saito et al. (8) has delivered adenovirusmediated $K L$ gene to atherosclerotic rats and ameliorated vascular endothelial dysfunction and increased nitric oxide production. These mechanisms are also very similar to the pathway of genes involving $K L$, e-NOS and CAT correlation with aging in our study.

\section{Conclusion}

Various in vitro and animal studies have demonstrated that many genes involving $K L, C A T$ and e-NOS in aging and diseases related with aging, such as cardiovascular pathologies play important roles via different metabolic pathways. For that reason, their possible usage either as diagnostic markers or as therapeutic agents in the diagnosis and treatment of cardiovascular diseases may be of great importance in the future. As far as we investigated the related literature, the right and left side expression levels are compared for the first time in our study.

\section{Ethics}

Ethics Committee Approval: All experimental procedures were performed in accordance with the standards of the European Community guidelines on the care and use of laboratory animals and approved by the Ankara University with a reference number of 2016-18-165 in accordance with the guide for the care and use of laboratory animals.
Informed Consent: Experimental study.

Peer-review: Externally peer-reviewed.

\section{Authorship Contributions}

Surgical and Medical Practices: B.T., Concept: F.T., B.T., Design: F.T., B.T., Data Collection or Processing: T.Ö., Y.H., Analysis or Interpretation: F.T., T.Ö., Y.H., B.T., Literature Search: F.T., T.Ö., Y.H., Writing: F.T., T.Ö., Y.H.

Conflict of Interest: The authors have no conflicts of interest to declare.

Financial Disclosure: This study was supported by a grant from Scientific Research Projects of Ankara University (project no: $18 \mathrm{H} 0230002)$.

\section{References}

1. Lopez-Otin C, Blasco MA, Partridge $L$, et al. The hallmarks of aging. Cell. 2013;153:1194-1217.

2. Kuro-o $M$, Matsumura $Y$, Aizawa $H$, et al. Mutation of the mouse klotho gene leads to a syndrome resembling ageing. Nature. 1997;390:45-51.

3. Poelzl G, Ghadge SK, Messner M, et al. Klotho is upregulated in human cardiomyopathy independently of circulating Klotho levels. Sci Rep. doi: 10.1038/s41598-018-26539-6

4. Ji N, Luan J, Hu F, et al. Aerobic exercise-stimulated Klotho upregulation extends life span by attenuating the excess production of reactive oxygen species in the brain and kidney. Exp Ther Med. 2018;16:3511-3517.

5. Wang Y, Sun Z. Current understanding of klotho. Ageing Res Rev. 2009;8:4351 .

6. Wang $X$, Hu S, Liu L. Phosphorylation and acetylation modifications of FOX03a: Independently or synergistically? Oncol Lett. 2017;13:2867-2872.

7. Pathare G, Vk S, Shalia K. Emerging Roles of Klotho in Cardiovascular Diseases. JCCR. doi: 10.15406/jccr.2016.06.00228

8. Saito $Y$, Yamagishi $T$, Nakamura $T$, et al. Klotho protein protects against endothelial dysfunction. Biochem Biophys Res Commun. 1998;248:324-329.

9. Olgar $Y$, Turan B. A sodium-glucose cotransporter 2 (SGLT2) inhibitor dapagliflozin comparison with insulin shows important effects on $\mathrm{Zn}(2+)$ transporters in cardiomyocytes from insulin-resistant metabolic syndrome rats through inhibition of oxidative stress (1). Can J Physiol Pharmacol. 2019;97:528-535.

10. Georgiou A, Lisacek-Kiosoglous A, Yiallouris A, et al. Klotho: The Protein of Faith. Ecronicon. 2017:189-223.

11. Mitani $\mathrm{H}$, Ishizaka $\mathrm{N}$, Aizawa $\mathrm{T}$, et al. In vivo klotho gene transfer ameliorates angiotensin II-induced renal damage. Hypertension. 2002;39:838-843.

12. Jimbo $R$, Kawakami-Mori $F, M u ~ S$, et al. Fibroblast growth factor 23 accelerates phosphate-induced vascular calcification in the absence of Klotho deficiency. Kidney Int. 2014;85:1103-1111.

13. Aizawa H, Saito Y, Nakamura T, et al. Downregulation of the Klotho gene in the kidney under sustained circulatory stress in rats. Biochem Biophys Res Commun. 1998;249:865-871.

14. Xie J, Cha SK, An SW, et al. Cardioprotection by Klotho through downregulation of TRPC6 channels in the mouse heart. Nat Commun. doi: 10.1038/ncomms2240

15. Hu MC, Kuro-o M, Moe OW. Klotho and chronic kidney disease. Contrib Nephrol. 2013;180:47-63.

16. Alhusseini NF, AEDA El-Talees, Hussien NI, Arafat NN. The Effects of Exercise and Antioxidant on Klotho Gene Expression During Oxidative Stress in Rat's Cardiac Tissue. SDRP Journal of Cellular and Molecular Physiology. 2016;1:15-24. 
17. Ai F, Chen M, Li W, et al. Protective role of Klotho on cardiomyocytes upon hypoxia/reoxygenation via downregulation of Akt and FOXO1 phosphorylation. Mol Med Rep. 2014;11:2013-2019.

18. Aguilar-Alonso P, Vera-Lopez O, Brambila-Colombres E, et al. Evaluation of Oxidative Stress in Cardiomyocytes during the Aging Process in Rats Treated with Resveratrol. Oxid Med Cell Longev. 2018;2018:1-9.

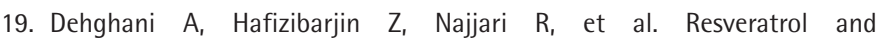
1,25-dihydroxyvitamin $\mathrm{D}$ co-administration protects the heart against
D-galactose-induced aging in rats: evaluation of serum and cardiac levels of klotho. Aging Clin Exp Res. 2018;31:1195-1205.

20. Torella $D$, Leosco $D$, Indolfi $C$, et al. Aging exacerbates negative remodeling and impairs endothelial regeneration after balloon injury. Am J Physiol Heart Circ Physiol. 2004;287:H2850-H2860.

21. Griecsova L, Farkasova V, Gablovsky I, et al. Effect of maturation on the resistance of rat hearts against ischemia. Study of potential molecular mechanisms. Physiol Res. 2015:S685-S696. 